\title{
Population Movement and Virus Spreading:HEV Spreading in a Pilgrimage City, Mashhad in Northeast Iran; an Example
}

\author{
Sanaz Ahmadi Ghezeldasht ${ }^{1}$, Rahele Miri ${ }^{1}$, Mohamadreza Hedayatimoghadam ${ }^{1}$, Aliakbar \\ Shamsian ${ }^{2}$, Hamidreza Bidkhori ${ }^{1}$, Fahad Fathimoghadam ${ }^{1}$, Seyyed. Abdorrahim. Rezaee \\ $1,3,{ }^{*}$ \\ ${ }_{2}^{1}$ Research Center for HIV/AIDS, HTLV and Viral Hepatitis, Iranian Academic Center for Education, Culture and Research (ACECR), Mashhad, IR Iran \\ ${ }_{3}^{2}$ Academic Center for Education, Culture and Research (ACECR), Mashhad, IR Iran \\ ${ }^{3}$ Immunology Research Center, Mashhad University of Medical Sciences, Mashhad, IR Iran \\ ${ }^{*}$ Corresponding author: Seyyed. Abdorrahim. Rezaee, Research Center for HIV/AIDS, HTLV and Viral Hepatitis, Iranian Academic Center for Education, Culture and Research (ACECR), \\ Mashhad, IR Iran. Tel: +98-5118821533, Fax: +98-5118810177, E-mail: rezaeer@mums.ac.ir.
}

Received: January 15, 2013; Revised: April 21, 2013; Accepted: Jun 25, 2013

Background:Hepatitis E Virus (HEV) infection is a significant public health concern and responsible for large outbreaks of acute hepatitis in poor sanitary and living conditions.

Objectives: To investigate the impact of population movements on virus spreading, a large-scale population-based survey was performed in a pilgrimage-tourism area, the great Mashhad, capital city of Khorasan province.

Patients and Methods: A cross-sectional study was carried out among 1582 randomly selected individuals from general population of Mashhad, north east of Iran, between May to September 2009. Serum samples were tested for total anti-HEV antibody using a specific enzyme linked immunoassay (ELISA) kit.

Results: The prevalence of HEV infection was $14.2 \%$ (225/1582) with a maximum of $25.5 \%(14 / 55)$ in densely populated areas. The highest prevalence was observed in visitant areas ( $\geq 20 \%$ )near the holly shrine with crowded hotels and inns. The differences between these areas and other districts were statistically significant $(\mathrm{P}<0.001)$. The findings indicated that $13.2 \%(95 / 718)$ of males and $15.0 \%$ (130/864) of females were HEV positive; this difference is not significant. Seroprevalence increases with age rising, from $12.8 \%$ in subjects less than five years to $28.6 \%$ in individuals with more than 65 years old. Although, there were no meaningful differences between HEV seropositivity and socioeconomic status, Illiterate individuals were significantly at higher risk for infection than educated persons $(\mathrm{P}<0.001)$.

Conclusions: These findings demonstrated that, high prevalence of HEV is related to populated district, which can reach to the highest rate in hotels and inns close to visitants. Traditional sanitation and water supplying systems are the second important factor for the virus transmission. Therefore, it can be concluded that such areas need efficient surveillance systems to prevent the spreading of infectious diseases.

Keywords: Hepatitis E Virus; Population; Viruses

\section{Background}

Epidemiological studies have shown that hepatitis E virus (HEV) infection is a significant public health concern in many parts of the world, causing large outbreaks of acute hepatitis. This virus was first recognized in the early 1980 s (1) and known as the causative agent of hepatitis E. HEV is a small, non-enveloped, single-stranded RNA virus, approximately 27-34 $\mathrm{nm}$ in diameter. In most recent ICTV (International Committee on Taxonomy of Viruses) classification, HEV has been placed in its own taxonomic group "Hepatitis E-like viruses" as a member of the genus Hepevirus in the Hepeviridae family (2), within the class IV positive sense RNA viruses (3). The viral particles are relatively stable in the environment and have been recovered from sewage samples (4). Since the first documented hepatitis E outbreak in India during 1955-1956, there have been many large outbreaks reported in developing countries of Southeast and Central Asia, the Middle East, northern and western parts of Africa (5-9). In contrast, in developed countries, there have been sporadic cases of locally acquired hepatitis E, even though; no epidemics have been reported $(10,11)$. Although the overall mortality rate associated with HEV infection is low, it is reportedly as high as $20 \%$ among infected pregnant women particularly during the third trimester of pregnancy $(12,13)$,children younger than two years old, $(14,15)$ organ recipients,

Implication for health policy/practice/research/medical education:

These findings demonstrated that, high prevalence of HEV is related to populated district which can reach to the highest rate in hotels and inns close to visitants.The results in the present study show that establishment of a good plan in order to prepare healthy environment for pilgrimage season in overcrowded areas could not only prevent spreading of viruses among residents of such big cities, it is also important to eliminate the chance of spreading the infectious diseases, particularly hepatitis around the country.

Copyright (c) 2013, KowsarCorp.; Licensee Kowsar Ltd. This is an Open Access article distributed under the terms of the Creative Commons Attribution License (http:| creativecommons.org/licenses/by/3.0), which permits unrestricted use, distribution, and reproduction in any medium, provided the original work is properly cited. 
$(16,17)$ other severely immunocompromised subjects (18) and in blood products recipients (19). The infection has been primarily described to be associated with the ingestion of fecally contaminated drinking water as a waterborne disease (12). However, recent investigations have not consistently found well-defined water sources of HEV, suggesting other possible routes of transmission $(14,20)$. These other transmission modes may be related to the level of population immunity, sanitary conditions, living conditions and other factors (21). Other frequent routes of transmission have been demonstrated such as blood transfusion and person to person (22). It is also considerable that, in some populations, HEV appears to be easily transmissible with up to $76 \%$ of people aged $>20$ years old having serological evidence of infection without any significant disease (23). Where hepatitis E is hyperendemic or not, the frequency of various transmission routes, the affected groups and disease characteristics differ sufficiently in different areas.

The HEV genotypes prevalent in regions with different patterns of disease epidemiology vary and these may determine some of the differences in disease epidemiology in these regions (24). Mashhad as the main city in north east of Iran and the capital city of Khorasan, is a populated holly city for Muslims which is located near the geographical border of Afghanistan and Turkmenistan. The motives of mobility, the process of the international movement, particularly those from in countries at war with poor sanitary conditions such as Iraq and Afghanistan $(25,26)$ and the back and forth transition between differential risk environments should be considered for management of HEV infection in immigrant-receiving metropolitan areas such as Mashhad. Moreover, the main source of water distribution either piped line or other water supply systems, for drinking and household needs, during drought since 2000 in the region, have been the underground water in the city. On this period, sewage is disposed in traditional way and was not connected to the local network of urban sewage disposal system.

Therefore, pilgrimage, immigration, tourism and traditional sewage system may alter the epidemiology of HEV infection from other parts of the country. To our knowledge, few studies have addressed the prevalence of HEV infection in pilgrimage and tourism region, particularly in Iran. The current study was conducted to investigate the sero-epidemiology of HEV among general population in this region that have a huge mobile population and accepted immigrants and asylum seekers, mostly from Iraq and Afghanistan.

\section{Objective}

Hepatitis E Virus (HEV) infection is found worldwide and is responsible for large outbreaks in East and South Asia. To investigate the impact of population movement on virus spreading, a large-scale population-based survey was performed in a pilgrimage-tourism area, the great Mashhad, capital city of Khorasan province.

\section{Patients and Methods}

This analysis is a cross-sectional study that was conducted in 2012 in the Academic Center for Education, Culture and Research (ACECR) Mashhad branch, Iran. Blood samples were taken after obtaining an informed consent and the sera were stored at -20 until test performance. The source survey of this study was performed on the general population of Mashhad the great, between May and September 2009. The subjects were selected randomly by multistage sampling methods (stratified, cluster, and systematic) from all of twelve municipality areas and forty districts of the city. In each household, one person was selected so that we tried to include equal ratios of the both sexes as well as ten percentiles for the age according to the 2006 census in each district.

Whole blood sample were collected and sera were assessed for total anti-HEV antibody using a commercial specific enzyme-linked immunosorbant assay (ELISA) kit (Diapro, Italy) according to the manufacturer's instruction. Data were analyzed with SPSS software using Chisquare, fisher and T-test. Statistical significance was set at $\mathrm{P}<0.05$. A multivariate logistic regression analysis was performed to identify variables that were independently associated with presence of anti-HEV.

\section{Results}

\subsection{Seroprevalence of $H E V$}

Total of 1582 were assayed for HEV total antibody. The mean age was $29.06 \pm 18.513$ years, range from one to 90 years old, 718 (45.38\%) were male and 864 (54.62\%) were female. The overall seroprevalence of HEV in this population was $14.2 \%(225 / 1582)$.

Furthermore, $3.0 \%$ (47/1582) of the whole study population were in the range of equivocal results. The finding indicated that $13.2 \%$ (95/718) of males and 15.0\% (130/864) of female were HEV positive; however, the difference was not statistically significant. Furthermore as, Table 1 shows that the seroprevalence of HEV increased significantly with rising the age, from $12.8 \%$ in subjects less than five years to $28.6 \%$ in individuals with 65 years old and over. Therefore, a higher prevalence of anti-HEV positivity was seen in older subjects $(\mathrm{P}<0.001)$. 
Ahmadi Ghezeldasht S et al.

\begin{tabular}{|c|c|c|c|c|}
\hline \multirow[t]{2}{*}{ Age group } & \multicolumn{3}{|c|}{ HEV infection } & \multirow{2}{*}{$\begin{array}{l}\text { Total Count (Within } \\
\text { Age Group), No. (\%) }\end{array}$} \\
\hline & $\begin{array}{l}\text { Negative Count } \\
\text { (Within Age Group), } \\
\text { No. }(\%)\end{array}$ & $\begin{array}{l}\text { Equivocal Count } \\
\text { (Within Age Group), } \\
\text { No. (\%) }\end{array}$ & $\begin{array}{l}\text { Positive Count } \\
\text { (Within Age Group), } \\
\text { No. (\%) }\end{array}$ & \\
\hline$<5$ & $75(87.2)$ & $0(0.0)$ & $11(12.8)$ & $86(100.0)$ \\
\hline $5-14$ & $240(89.2)$ & $5(1.9)$ & $24(8.9)$ & $269(100.0)$ \\
\hline $15-24$ & 364 (89.7) & $8(2.0)$ & $34(8.4)$ & $406(100.0)$ \\
\hline $25-34$ & $253(84.6)$ & $12(4.0)$ & $34(11.4)$ & $299(100.0)$ \\
\hline $35-44$ & $147(78.6)$ & $5(2.7)$ & $35(18.7)$ & $187(100.0)$ \\
\hline $45-54$ & $113(71.5)$ & $9(5.7)$ & $36(22.8)$ & $158(100.0)$ \\
\hline $55-64$ & $69(69.0)$ & $2(2.0)$ & $29(29.0)$ & $100(100.0)$ \\
\hline$>=65$ & $49(63.6)$ & $6(7.8)$ & $22(28.6)$ & $77(100.0)$ \\
\hline$<5$ & $75(87.2)$ & $0(0.0)$ & $11(12.8)$ & $86(100.0)$ \\
\hline
\end{tabular}

4.2. The Seroprevalence of HEV and Socio-Economic Status
There were not any statistically significant relations between HEV seropositivity and socioeconomic status such as income, marital status and mother's educational level.

Table 2. Literacy Level and HEV Infection

\begin{tabular}{lllll}
\hline Literacy level & \multicolumn{4}{c}{ HEV infection } \\
\cline { 2 - 5 } & $\begin{array}{l}\text { Negative Count } \\
\text { (within literacy level) }\end{array}$ & $\begin{array}{l}\text { Negative Count } \\
\text { (within literacy level) }\end{array}$ & $\begin{array}{l}\text { Negative Count } \\
\text { (within literacy level) }\end{array}$ & $\begin{array}{l}\text { Negative Count } \\
\text { (within literacy level) }\end{array}$ \\
\hline $\begin{array}{l}\text { Illiterate } \\
\text { Literate }\end{array}$ & $88(64.2)$ & $30(28.3)$ & $106(100.0)$ \\
$\quad \begin{array}{l}\text { Primary-Second- } \\
\text { ary School }\end{array}$ & $495(82.0)$ & $16(2.6)$ & $93(15.4)$ & $604(100.0)$ \\
$\quad \begin{array}{l}\text { High School-Pre } \\
\text { university }\end{array}$ & $413(85.9)$ & $16(3.3)$ & $52(10.8)$ & $481(100.0)$ \\
$\quad \begin{array}{l}\text { Academic } \\
\text { Ande) }\end{array}$ & $6(2.3)$ & $33(12.8)$ & $258(100.0)$
\end{tabular}

However, there was a meaningful relation between illiteracy and HEV sero-prevalence $(P<0.001)$. Illiterate individuals were at higher risk of infection than educated persons (Table 2).

\subsection{The Seroprevalence of HEV in Twelve Munici- pality Areas of Mashhad}

HEV antigen was considerably different among different districts in twelve municipality areas of Mashhad. As Figure 1 shows a significant difference $(\mathrm{P}<0.001)$ was observed between HEV prevalence and the place of living in twelve different municipality areas of the city. HEV was detected in patients from almost all districts of Mashhad, including; the lowest rate in 12 th district (4.2\%), with the fewest Mashhadi residents, and the highest percentages in the 8 th district (25.5\%), a densely populated area (city center) with high density of hotels and inns.

\section{Discussion}

The present study is the largest population-based seroepidemiological work of HEV infection in Iran and the first conducted in a pilgrimage tourism area in north east of the country. Hepatitis $\mathrm{E}$ is an important public health concern in many developing countries of Asia and Africa particularly drought and war stricken regions, where environmental sanitation facilities are poor, $(27,28)$. Large outbreaks of hepatitis E were observed in, India, Pakistan, Nepal, Myanmar, China and East Africa (29). Usually hepatitis E occurs in areas with a high population density, lowlands, and valley areas. The incidence and prevalence rate of HEV infection is underestimated due to unavailability of laboratory services in endemic territories. It is believed that in India at least one half of acute sporadic viral hepatitis cases are etiologically associated with HEV (30). Iran is located between Iraq and Turkey in the west, Afghanistan and Pakistan in the east on border. 
Mashhad as the main city in north east of Iran is a holly city which is located near the geographical border of Afghanistan and Turkmenistan. Mashhad, with population of Three million people (census 2006), attracts more than 25 million tourists and pilgrims every year. Therefore, pilgrimage, immigration and tourism may alter the epidemiology of HEV infection compare to the whole country.

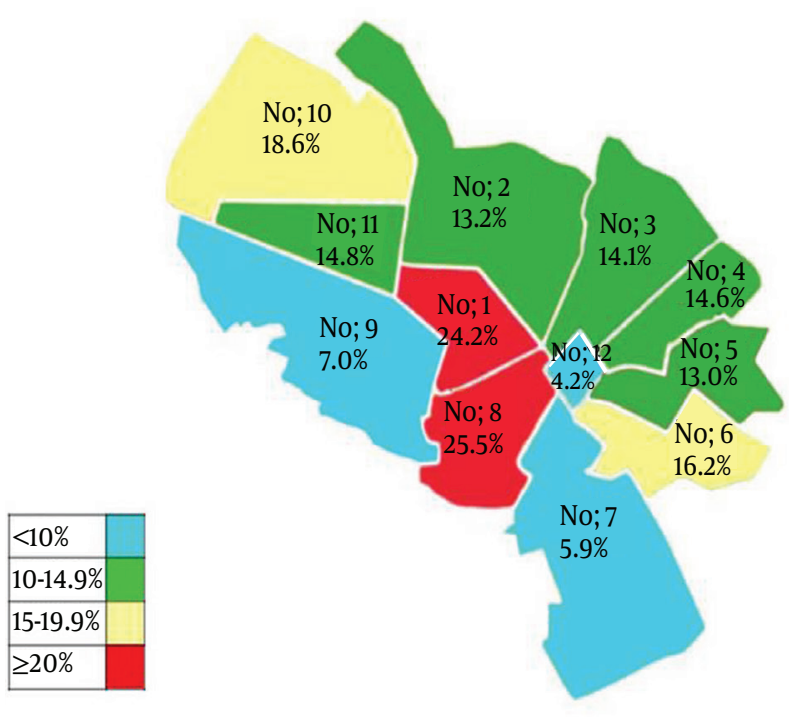

Figure 1. Distribution of HEV Prevalence in Twelve Municipality Areas of Mashhad

The results of study on the overall HEV prevalence were $14.2 \%$, which is higher than several previous populationbased studies and reports among general population in Iran $(28,31,32)$. A report from general population in Mazandaran (North of Iran) revealed that $1.1 \%$ of children younger than 10 years and $7.2 \%$ of population between 20 and 25 years old were positive for anti-HEV IgG antibody (33). A study in Nahavand, a city in Hamadan province, has shown 9.3\% HEV prevalence in general population (32). A report from Isfahan revealed that the overall antiHEV seroprevalence was 3.8\% in general population (34). The prevalence is even different in various cities in a certain population, which is $7.4 \%$ on hemodialysis patients in Tabriz (35) and 7\% in Jahrom (36), 27.5\% in East Azerbaijan on patients with chronic liver disease (37) and $11.5 \%$ in Khuzestan on Blood donor(28). Difference of HEV prevalence in the general population, the criteria for inclusion of samples, mobile populations, tourism and pilgrimage, sewage disposal and the routes of HEV transmission could partially explain the diverse results. The results of the present study is less than general population in Pakistan (17.5\%) (38). There is only one study of outbreak in Afghanistan revealed that during 2004-2005, the prevalence of anti-HEV in veterans who have had their military service in Afghanistan was 29.97\% (39). In Iran, the large cities have better public health services, such as clinics,

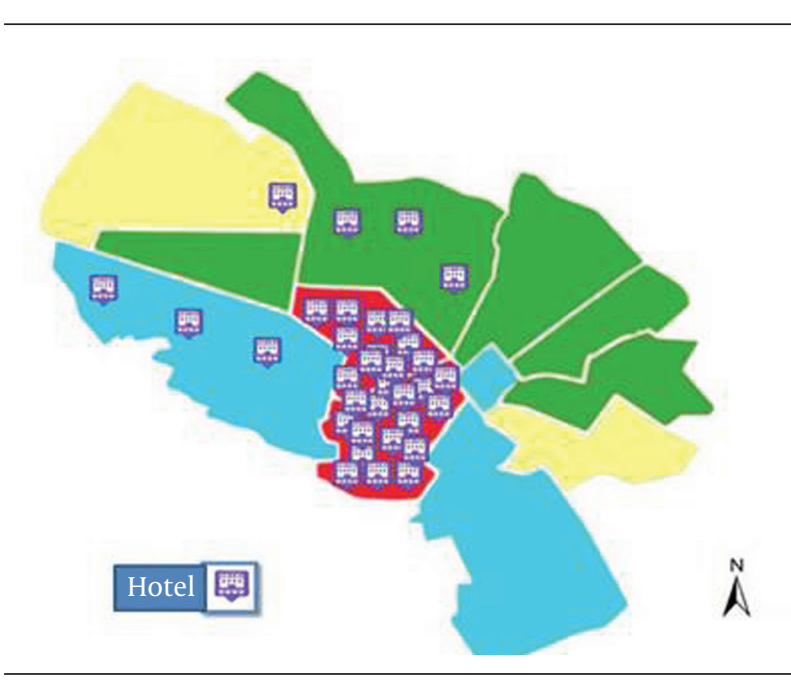

Figure 2. Distribution of Hotels in Mashhad

municipal water and sewage systems, possibly explaining the reduced risk of infection; However, Mashhad as a popular pilgrimage city and in neighborhood with HEV high prevalence regions was accounted as an endemic city for hepatitis E. HEV seropositivity has been mainly reported in males $(28,40)$. However, most studies in Iran fail to demonstrate any significant differences between male and female $(31,33,34,37)$. The results of this study also confirmed which HEV infection is not significantly related to gender. The seroprevalence increased significantly with rising age $(\mathrm{P}<0.001)$. Except two studies, $(41$, 42 ) the results of the most previous studies in Iran have shown that HEV seropositivity is $(32,34,37,43,44)$ lower in educated populations compared to the uneducated. However, the differences were not significant $(32,34$, $37,43,45)$. In the present study, the results supported a strong relationship between HEV seropositivity and illit$\operatorname{eracy}(\mathrm{P}<0.001)$.

Contaminated water is a potential source for the spread of this transmissible enteric disease. Pigs and animals have a minor role in HEV infection in our region. During drought, beginning from 2000, water resources in Mashhad has been turned to underground water. However, the sewage from the city, houses, and factories, is mainly disposed in traditional way and was not connected to the local network of urban sewage disposal system, mainly in city center. As Figure 1 shows, the high prevalence of HEV appears in district, No 1 and 8 municipalities of the city where sewage disposal system is currently (2010) connected to the water supply system of Iran-Turkmenistan Friendship Dam.

Usually hepatitis E occurs in areas with a high population density (44). The population density is not the main factor for virus spreading among population. Problems may rise when different mobile populations mixed up with the visitants from all parts of the world result in overcrowding. Population movement from HEV high 
prevalence areas to populated residential areas and overcrowding is happening during Muslim's holly months in Mashhad; hence, the rate of virus transmission should be very high. Thus, the high density of population in some municipality areas of the holly Mashhad, explains the high prevalence of HEV. As it was mentioned above, Mashhad has a mixed population of residents and travelers with close contact. Therefore, mobile population settled in hotels and inns in specified regions near holly shrine from different departures could easily spread the communicable infections. On the other hand, preparing healthy environment in such situation for residents is hardly achievable, due to the close contact between the visitants and unhealthy environment. As Figure 2 shows, these factors might result in the high prevalence of hepatitis E in those municipality areas of Mashhad. Migration and population mobility are associated with continuing and increasing infectious diseases such as HEV that could effectively be controlled if those factors are taken into consideration.

Taken together, the poor maintenance of the sewage disposal system and the drinking water supply line from underground water, overcrowded area, unhealthy environment during pilgrimage seasons and emigration may have resulted in the high prevalence of HEV in Mashhad, which is even higher than war stricken areas in country such as Khuzestan (28). Prevention of hepatitis E relies primarily on the provision of clean water supplies, preparing sanitary water for agriculture, especially vegetables, avoiding contamination of water pipelines with sources of infection and establishing proper disposal systems. Furthermore, the results in the present study show that establishment of a good plan in order to prepare healthy environment for pilgrimage season in overcrowded areas could not only prevent spreading of viruses among residents of such big cities, but also eliminate the chance of spreading the infectious diseases, particularly hepatitis around the country. In addition, clinicians in such area should be aware and consider that the emergent of infections such as HEV, could be presented with unexplained signs and symptoms. In case of HEV, due to narrow window for diagnosis, prompt collection of samples for laboratory testing should be considered.

\section{Acknowledgements}

This study was granted by Academic Center for Education, Culture and research (ACECR), Mashhad branch and has been performed in Medical Central Lab. The authors would like to thank Mrs Rosita Vakili, for proof reading of the manuscript and valuable comments.

\section{Author's Contribution}

Sanaz Ahmadi Ghezeldasht: Performing the tests and prepareing the draft. Dr Rahele Miri: Supervising of sampling, visiting the seropositive cases. Mohamadreza Hedayatimoghadam: the statistician of the study. Determining sample size, random sample selection, Statistical analysis. Aliakbar Shamsian: Supervision of the tests, preparing the fund. Hamidreza Bidkhori , Fahad Fathimoghadam :Supervision of the sampling, consultation Seyyed. abdorrahim. Rezaee : Introducing the idea. Writing the proposal, study coordination, writing the manuscript.

\section{Financial Disclosure}

The authors declare no conflict of interest related to this work.

\section{Funding/Support}

This study was jointly supported by grants from the Academic Center for Education, Culture and research, Mashhad branch.

\section{References}

1. Balayan MS, Andjaparidze AG, Savinskaya SS, Ketiladze ES, Braginsky DM, Savinov AP, et al. Evidence for a virus in non-A, non-B hepatitis transmitted via the fecal-oral route. Intervirology. 1983;20(1):23-31.

2. Cossaboom CM, Cordoba L, Cao D, Ni YY, Meng XJ. Complete genome sequence of hepatitis $\mathrm{E}$ virus from rabbits in the United States. J Virol. 2012;86(23):13124-5.

3. Pringle CR. Virus taxonomy-1999. The universal system of virus taxonomy, updated to include the new proposals ratified by the International Committee on Taxonomy of Viruses during 1998. Arch Virol.1999;144(2):421-9.

4. Clemente-Casares P, Pina S, Buti M, Jardi R, MartIn M, Bofill-Mas S, et al. Hepatitis E virus epidemiology in industrialized countries. Emerg Infect Dis. 2003;9(4):448-54.

5. Viswanathan R. A review of the literature on the epidemiology of infectious hepatitis. Indian J Med Res. 1957;45(Suppl.):145-55.

6. Khuroo MS. Study of an epidemic of non-A, non-B hepatitis: Possibility of another human hepatitis virus distinct from posttransfusion non-A, non-B type. The American journal of medicine. 1980;68(6):818-24.

7. Arora NK, Panda SK, Nanda SK, Ansari IH, Joshi S, Dixit R, et al. Hepatitis E infection in children: study of an outbreak. J Gastroenterol Hepatol.1999;14(6):572-7.

8. Naik SR, Aggarwal R, Salunke PN, Mehrotra NN. A large waterborne viral hepatitis E epidemic in Kanpur, India. Bull World Health Organ.1992;70(5):597-604.

9. Velazquez O, Stetler HC, Avila C, Ornelas G, Alvarez C, Hadler SC, et al. Epidemic transmission of enterically transmitted non-A, nonB hepatitis in Mexico, 1986-1987. JAMA. 1990;263(24):3281-5.

10. Lewis HC, Boisson S, Ijaz S, Hewitt K, Ngui SL, Boxall E, et al. Hepatitis E in England and Wales. Emerg Infect Dis. 2008;14(1):165-7.

11. Mansuy JM, Peron JM, Abravanel F, Poirson H, Dubois M, Miedouge $\mathrm{M}$, et al. Hepatitis $\mathrm{E}$ in the south west of France in individuals who have never visited an endemic area. J Med Virol. 2004;74(3):419-24.

12. Balayan MS. Epidemiology of hepatitis E virus infection. J Viral Hepat. 1997;4(3):155-65.

13. Hussaini SH, Skidmore SJ, Richardson P, Sherratt LM, Cooper BT, O'Grady JG. Severe hepatitis E infection during pregnancy. J Viral Hepat. 1997;4(1):51-4.

14. Teshale EH, Howard CM, Grytdal SP, Handzel TR, Barry V, Kamili S, et al. Hepatitis E epidemic, Uganda. Emerg Infect Dis. 2010;16(1):126-9.

15. Sharapov MB, Favorov MO, Yashina TL, Brown MS, Onischenko GG, Margolis HS, et al. Acute viral hepatitis morbidity and mor- 
tality associated with hepatitis E virus infection: Uzbekistan surveillance data. BMC Infect Dis. 2009;9:35.

16. Haagsma EB, van den Berg AP, Porte RJ, Benne CA, Vennema H, Reimerink JH, et al. Chronic hepatitis E virus infection in liver transplant recipients. Liver Transpl. 2008;14(4):547-53.

17. Kamar N, Selves J, Mansuy JM, Ouezzani L, Peron JM, Guitard J, et al. Hepatitis E virus and chronic hepatitis in organ-transplant recipients. N Engl J Med. 2008;358(8):811-7.

18. Ollier L, Tieulie N, Sanderson F, Heudier P, Giordanengo V, Fuzibet JG, et al. Chronic hepatitis after hepatitis E virus infection in a patient with non-Hodgkin lymphoma taking rituximab. Ann Intern Med. 2009;150(6):430-1.

19. Tamura A, Shimizu YK, Tanaka T, Kuroda K, Arakawa Y, Takahashi $\mathrm{K}$, et al. Persistent infection of hepatitis E virus transmitted by blood transfusion in a patient with T-cell lymphoma. Hepatol Res. 2007;37(2):113-20.

20. Teshale EH, Grytdal SP, Howard C, Barry V, Kamili S, Drobeniuc J, et al. Evidence of person-to-person transmission of hepatitis $\mathrm{E}$ virus during a large outbreak in Northern Uganda. Clin Infect Dis. 2010;50(7):1006-10.

21. Teshale EH, Hu DJ, Holmberg SD. The two faces of hepatitis E virus. Clin Infect Dis. 2010;51(3):328-34.

22. Khuroo MS, Kamili S, Yattoo GN. Hepatitis E virus infection may be transmitted through blood transfusions in an endemic area.J Gastroenterol Hepatol. 2004;19(7):778-84.

23. Fix AD, Abdel-Hamid M, Purcell RH, Shehata MH, Abdel-Aziz F, Mikhail N, et al. Prevalence of antibodies to hepatitis E in two rural Egyptian communities. Am J Trop Med Hyg. 2000;62(4):519-23.

24. Krawczynski K, Kamili S, Aggarwal R. Global epidemiology and medical aspects of hepatitis E. Forum (Genova). 2001;11(2):166-79.

25. Wallace MR, Hale BR, Utz GC, Olson PE, Earhart KC, Thornton SA, et al. Endemic infectious diseases of Afghanistan. Clin Infect Dis. 2002;34(Suppl 5):S171-207.

26. Utba NM. The prevalence of hepatitis E virus in Al-Sadr City Baghdad. Clin Lab. 2013;59(1-2):115-20.

27. Smith JL. A review of hepatitis E virus. J Food Prot. 2001;64(4):57286.

28. Assarehzadegan MA, Shakerinejad G, Amini A, Rezaee SA. Seroprevalence of hepatitis E virus in blood donors in Khuzestan Province, southwest Iran. Int J Infect Dis. 2008;12(4):387-90.

29. Beliakov VD, Ovezov AO, Khozhimirzaev A, Rozina VF, Khozhimirzaeva DZ, Gasanov E, et al. [Retrospective epidemiologic diagnosis of viral non-A, non-B hepatitis with a fecal-oral mechanism of transmission of the causative agent]. Zh Mikrobiol Epidemiol Immunobiol.1990;(3):44-8.

30. Khuroo MS, Rustgi VK, Dawson GJ, Mushahwar IK, Yattoo GN, Kamili S, et al. Spectrum of hepatitis $\mathrm{E}$ virus infection in India.J Med Virol. 1994;43(3):281-6.

31. Aminiafshar SAM, Gachkar L, Yousefi F, Attarchi Z. Anti hepatitis
E virus seropositivity in a group of blood donors. Iranian J Publ Health. 2004;33:53-6.

32. Taremi M, Mohammad Alizadeh AH, Ardalan A, Ansari S, Zali MR. Seroprevalence of hepatitis $E$ in Nahavand, Islamic Republic of Iran: a population-based study. East Mediterr Health J. 2008;14(1):157-62.

33. Safar MJ, K AF, R., Babamohmoodi F. Seroepidemiology of HEV infection in 2-25 years of saravi in 2004. J Mazandaran Univ Med Sci. J Mazandaran Univ Med Sci. 2005;75:82-5.

34. Ataei B, Nokhodian Z, Javadi AA, Kassaian N, Shoaei P, Farajzadegan Z, et al. Hepatitis E virus in Isfahan Province: a populationbased study. Int J Infect Dis. 2009;13(1):67-71.

35. Taremi M, Khoshbaten M, Gachkar L, EhsaniArdakani M, Zali M. Hepatitis $\mathrm{E}$ virus infection in hemodialysis patients: a seroepidemiological survey in Iran. BMC Infect Dis. 2005;5:36.

36. Pourahmad M, Sotoodeh A, Nasiri H. Hepatitis E Virus Infection in Hemodialysis Patients: A Seroepidemiological Survey in Jahrom, Southern Iran. Hepat Mon. 200 9;9(3):232-5.

37. Somi M, Farhang S, Majid G, Shavakhi A, Pouri A. Seroprevalence of Hepatitis E in Patients with Chronic Liver Disease from East Azerbaijan, Iran. Hepat Mon. 2007;7(3):127-30.

38. Hamid SS, Atiq M, Shehzad F, Yasmeen A, Nissa T, Salam A, et al. Hepatitis $\mathrm{E}$ virus superinfection in patients with chronic liver disease. Hepatology. 2002;36(2):474-8.

39. Labrique A, Nelson K. Hepatitis E virus infections among US military personnel deployed to Afghanistan. $J$ Infect Dis. 2010;202(9):1297-9.

40. Purcell RE. Hepatitis E Virus. Philadelphia, PA:Lippincott:Williams and Wilkins; 2001.

41. Taremi M, Gachkar L, MahmoudArabi S, Kheradpezhouh M, Khoshbaten M. Prevalence of antibodies to hepatitis E virus among male blood donors in Tabriz, Islamic Republic of Iran. East Mediterr Health J. 2007;13(1):98-102.

42. Saffar MJ, Farhadi R, Ajami A, Khalilian AR, Babamahmodi F, Saffar H. Seroepidemiology of hepatitis E virus infection in 2-25-year-olds in Sari district, Islamic Republic of Iran. East Mediterr Health J. 2009;15(1):136-42.

43. Sepanlou SG, RH., Amini-Kafiabad, Dayhim MR, Merat SA. Population-based Seroepidemiological Study on Hepatitis E Virus in Iran. ME J Digest Dis.;2(2).

44. Alavian S. Hepatitis E Virus Infection: A Neglected Problem in Our Region. Hepat Mon. 2006;7(3):119-21.

45. Alavi S, Ahmadi F, Ghasemirad M. Seroepidemiological Study of Hepatitis E Virus in Drug Addicts in Ahvaz, Southern Iran: 20052006. Hepat Mon. 2008;8(4):263-6. 